\title{
PEMBERIAN KO-KEMOTERAPI FRAKSI ETIL ASETAT AKAR PASAK BUMI (Eurycoma longifolia Jack) TERHADAP EKSPRESI PROTEIN NF-K $\beta$ PADA TIKUS SPRAGUE DAWLEY YANG DIINDUKSI DMBA
}

\author{
Kony Putriani ${ }^{1,}$ Laela Hayu Nurani ${ }^{1}$, Sitarina Widyarini ${ }^{2}$ \\ ${ }^{1}$ Program Pascasarjana Farmasi, Universitas Ahmad Dahlan, Yogyakarta \\ ${ }^{2}$ Program Studi Kedokteran Hewan, UGM Yogyakarta \\ Email: putrianikony@gmail.com
}

\begin{abstract}
ABSTRAK
Kanker payudara terjadi karena adanya paparan dari senyawa 7,12-dimethylbenz (a) antrasene (DMBA) yang bersifat mutagenik dan karsinogenik. Drug of choice untuk kanker payudara adalah Doxorubicin, namun menimbulkan efek samping dan toksik pada sel normal maka diperlukan penelitian ko-kemoterapi dalam hal ini digunakan fraksi etil asetat akar pasak bumi yang dapat bersifat sebagai antiinflamasi dan apoptosis. Penelitian ini adalah untuk menelusuri mekanisme ko-kemoterapi akar pasak bumi dan Doxorubicin terhadap ekspresi protein NF-K $\beta$ pada Tikus SD yang diinduksi DMBA. Akar pasak bumi (Eurycoma longifolia Jack) diekstraksi menggunakan pelarut etanol $70 \%$ dan difraksinasi menggunakan etil asetat. Fraksi etil asetat akar pasak bumi diuji mekanisme molekulernya secara in vivo terhadap 5 Kelompok tikus galur Sprague Dawley terdiri atas Kelompok 1 hanya diberi pakan dan minum, Kelompok 2 diberikan DMBA dosis $20 \mathrm{mg} / \mathrm{kgBB}$, Kelompok 3 diberikan DMBA $20 \mathrm{mg} / \mathrm{kgBB}+$ Doxorubicin $1,17 \mathrm{mg} / \mathrm{kgBB}$, Kelompok 4 diberikan DMBA $20 \mathrm{mg} / \mathrm{kgBB}$ + fraksi etil asetat akar pasak bumi $100 \mathrm{mg} / \mathrm{kgBB}$, Kelompok 5 diberikan DMBA $20 \mathrm{mg} / \mathrm{kgBB}$ + Doxorubicin $1,17 \mathrm{mg} / \mathrm{kgBB}$ + fraksi etil asetat akar pasak bumi $100 \mathrm{mg} / \mathrm{kgBB}$ kemudian dilakukan pembedahan dan uji imunohistokimia analisis data Kolmogorof Smirnof, uji Levene, uji ANOVA atau Kruskal Wallis. Hasil nilai rata-rata \% ekspresi protein NF-K $\beta$ adalah $(6,64 \pm 11,28) \%,(39,53 \pm 16,49) \%,(18,10 \pm 15,08 \%,(16,66 \pm$ $12,51) \%$ dan $(15,39 \pm 8,76) \%$. Kesimpulan dari penelitian ini adalah kombinasi fraksi etil asetat ekstrak etanol akar pasak bumi dan Doxorubicin dapat menurunkan ekspresi protein NF-K $\beta$ dan terhadap tikus galur Sprague Dawley yang diinduksi DMBA.
\end{abstract}

Kata Kunci: Akar Pasak Bumi (Eurycoma longifolia Jack), Kanker Payudara, NF-K $\beta$.

\section{PENDAHULUAN}

Kanker payudara merupakan keganasan yang sering ditemukan pada wanita, dengan insiden sebesar $20 \%$ dari seluruh keganasan [4]. Pengatasan kanker payudara selama ini dengan kemoterapi, pembedahan, serta radiasi. Kelemahan agen kemoterapi yang banyak digunakan dalam terapi kanker juga membunuh sel kanker namun juga bersifat toksik pada sel normal. Hal ini mengharuskan pemikiran dosis agen kemoterapi (yang sering digunakan untuk kanker payudara adalah doxorubicin) harus ditekan. Penambahan ko-kemoterapi merupakan pilihan yang tepat untuk mengatasi hal ini. Pemicu terjadinya kanker yaitu zat karsinogenik 7,12 dimetylbenz( $\alpha$ )antrasen (DMBA). Senyawa 7,12 dimetylbenz( $\alpha$ )antrasen akan mengaktifkan ROS, yang mana ROS ini nanti akan mengirimkan sinyal pada berbagai reseptor di cytosol untuk mengaktifkan NF-K $\beta, \quad \mathrm{NF}-\mathrm{K} \beta$ ini merupakan Keluarga protein dari salah 
satu keluarga faktor transkripsi yang penting dalam regulasi ekspresi gen yang terkait dengan fungsi-fungsi biologis seperti halnya respon imun dan inflamasi, pertumbuhan dan proliferasi sel, serta pertahanan sel terhadap stres seperti sinar UV, iradiasi, oksidan, kerusakan DNA, termasuk radiasi dari zat karsinogenik 7,12 dimetylbenz $(\alpha)$ antrasen yang dapat menyebabkan kanker[1].

Nuclear factor-kappa $\beta$ (NF-k $\beta$ ) mengatur ekspresi gen yang terlibat pada berbagai proses yang mempunyai peran dalam perkembangan serta progresifitas kanker seperti proliferasi, migrasi, dan apoptosis. Nuclear factor-kappa $\beta$ bukan suatu single gen, tetapi famili yang erat hubungannya dengan faktor transkripsi, termasuk 5 gen NF-k $\beta 1$ (p50/p105), NFkß2 (p52/p100), RelA (p65), c-Rel, dan RelB. Nuclear factor-kappa $\beta$ terlihat pada semua sel yang teraktivasi, yang mengatur ekspresi dari bermacam target gen yang mempromosi proliferasi sel, pengaturan imun, respons inflamasi, dan juga berkontribusi dalam patogenesis berbagai penyakit termasuk juga keganasan. Nuclear factor-kappa $\beta$ signaling pathway diregulasi oleh inhibitor kappa $\beta(\operatorname{Ik} \beta)$ family. Nuclear factor-kappa $\beta$ banyak terdapat dalam sitoplasma, NF-k $\beta$ akan berikatan dengan Ik $\beta$ yang akan menahan NF-k $\beta$ tetap berada dalam sitoplasma. Aktivasi NF-k $\beta$ pathway merupakan salah satu kunci mekanisme kelangsungan hidup pada berbagai tipe keganasan. [1].

\section{Senyawa}

7,12

dimetylbenz( $\alpha$ )antrasene (DMBA) akan memicu aktivasi RAS yang akan meningkatkan proliferasi dan menghambat apoptosis. Jalur RAS/MAPK memicu aktivasi protein COX-2 dan akan menginduksi pembentukan PGE2 dari asam arakidonat yang kemudian merangsang kembali jalur RAS/MAPK yang mengakibatkan peningkatan proliferasi. Begitu pula dengan NF-K $\beta$ (Nuclear factor-kappa $\beta$ ) banyak terdapat dalam sitoplasma. Protein NF-k $\beta$ akan berikatan dengan $\operatorname{Ik} \beta$ yang akan menahan NF-k $\beta$ tetap berada dalam sitoplasma. Aktivasi NF-k $\beta$ pathway merupakan salah satu kunci mekanisme kelangsungan hidup pada berbagai tipe sel keganasan [1].

Strategi yang tersedia untuk mengobati kanker payudara, dapat dilakukan dengan operasi, terapi radiasi, dan kemoterapi (terapi dengan obatobatan), contohnya Doxorubicin yang banyak digunakan dalam pengobatan kanker. Meskipun demikian ternyata penggunaan agen kemoterapi sistemik bukan saja tidak begitu efektif namun juga tidak selektif dan sangat toksik bagi jaringan lain yang normal [3], dengan toksisitasnya yang tinggi maka diperlukan penelitian Ko-kemoterapi dalam hal ini digunakan akar pasak bumi. Akar pasak bumi diteliti sebagai potensial agen antikanker terhadap kanker, kandungan yang dimiliki akar pasak bumi antara lain kuasinoid, alkaloid dan flavonoid [5]. Paparan dari akar pasak bumi yang mengandung senyawa Eurycomalactone, 14,15 $\beta$-dihydroklaieanone dan 13,21dehydroeurycomanone bisa digunakan sebagai inhibitor atau zat yang mencegah pengambatan aktivitas NF-K $\beta$ [6]. Aktivitas zat aktif kuasinoid ekstrak akar pasak bumi sebagai antikanker diduga melalui mekanisme pemacuan apoptosis atau penghambatan proliferasi sel kanker dengan melibatkan kerja enzim-enzim antioksidan dan respon imun seluler [7]. Tujuan penelitian ini adalah untuk menelusuri mekanisme seluler maupun molekuler dari kombinasi Akar Pasak Bumi dan Doxorubicin terhadap hewan uji model kanker dengan melihat ekspresi NF-K $\beta$.

\section{METODE PENELITIAN}

\section{Bahan}

Bahan yang akan digunakan adalah akar pasak bumi, CMC Na 0,5\%, corn oil (Superindo 365), 7,12 dimetilbenz(a)antrasen (DMBA) 20 
$\mathrm{mg} / \mathrm{KgBB} \quad$ (SIGMA Aldrich), Doxorubicin (OGB Sanbe $2 \mathrm{mg} / \mathrm{ml}$ ), etanol $70 \%$ (Genera Labora), formaldehid $10 \%, \mathrm{NaCl}$ fisiologis. Hewan uji yang akan digunakan pada penelitian ini adalah tikus betina galur SD (Sprague Dawley) dengan berat badan 100- 200 gram dan berumur 2 bulan.

\section{Pengumpulan Bahan}

Akar pasak bumi diperoleh dari Martapura, Kalimantan Selatan kemudian dibuat serbuk dan dikeringkan di Laboratorium Teknologi Sediaan Farmasi UAD.

\section{Ekstraksi akar pasak bumi}

Serbuk dengan ukuran mesh 20/40 sebanyak $5 \mathrm{~kg}$, dilakukan maserasi dengan etanol $70 \%$ menggunakan pengaduk elektrik, maserasi dilakukan selama 3 jam, kemudian didiamkan selama 24 jam. Setelah itu disaring hingga diperoleh filtrat dan rendemen. Filtrat kemudian disimpan, sedangkan rendemen yang ada dimaserasi kembali (remaserasi) sebanyak 1 kali. Filtrat yang ada dikumpulkan dan diuapkan menggunakan rotary evaporator kemudian diuapkan di atas waterbath pada suhu $70^{\circ} \mathrm{C}$ sampai diperoleh ekstrak kental.

\section{Pembuatan Fraksi Etil asetat}

Sebanyak 50 gram ekstrak etanol difraksi menggunakan $20 \mathrm{~mL}$ etil asetat dan dilakukan dengan cara enap tuang sebanyak 5 kali. Fraksinasi dilakukan sampai senyawa yang harus masuk ke dalam etil asetat tersari semua yang ditunjukkan oleh hasil KLT yang terlihat terpisah antara fraksi larut etil asetat dan tak larut etil asetat. Fraksi kemudian dipekatkan sehingga diperoleh fraksi larut etil asetat dan tak larut etil asetat.

\section{Pembuatan Larutan karsinogen 7,12- Dimetilbenz(a)antrasen (DMBA)}

Larutan karsinogen DMBA dapat dibuat dengan pelarut minyak jagung (Corn Oil). Larutan DMBA kemudian dipejankan secara peroral pada hewan uji dengan dosis $20 \mathrm{mg} / \mathrm{kgBB}$ selama 5 minggu dengan pemberian 2 kali seminggu. Larutan DMBA dibuat dengan melarutkan sejumlah DMBA, sesuai dosis, dengan minyak jagung sampai diperoleh larutan dengan konsentrasi yang jika diberikan pada hewan uji akan mendapatkan volume pemberian antara 0,5-1,5 mL. Larutan DMBA selalu dibuat baru, sebelum diberikan kepada hewan uji.

\section{Pembuatan Sampel Uji}

Fraksi etil asetat ekstrak etanol akar pasak bumi dilarutkan dalam CMC$\mathrm{Na}$ 0,5\%. Pembuatan CMC-Na dilakukan dengan pemanasan campuran CMC-Na dan akuades hingga $100^{\circ} \mathrm{C}$ yang disertai pengadukan menggunakan magnetic stirrer. Pelarutan fraksi etil asetat ekstrak etanol akar pasak bumi dalam CMC-Na.

\section{Pengelompokkan Hewan Uji}

Kelompok perlakuan tersebut terdiri dari Kelompok I sebagai Normal. Kelompok ini hanya diberikan makan dan minum setiap harinya; Kelompok II sebagai kontrol sakit yaitu Kelompok yang diberikan DMBA $20 \mathrm{mg} / \mathrm{kg}$ BB selama 5 minggu sebanyak $2 x$ seminggu dimulai dari minggu ke-1 sampai minggu ke-5; Kelompok III yaitu Kelompok yang diberikan DMBA $20 \mathrm{mg} / \mathrm{kg}$ BB dan Doxorubicin $1,17 \mathrm{mg} / \mathrm{kg} \mathrm{BB}$ selama 5 minggu sebanyak $1 \mathrm{x}$ seminggu dimulai dari minggu ke-6 sampai ke-10; Kelompok IV yaitu Kelompok yang diberikan DMBA $20 \mathrm{mg} / \mathrm{kg}$ BB dan fraksi etil asetat akar pasak bumi $100 \mathrm{mg} / \mathrm{kg} \mathrm{BB}$ selama 10 minggu dimulai dari minggu ke-6 sampai minggu ke-16; Kelompok V yaitu Kelompok yang diberikan DMBA $20 \mathrm{mg} / \mathrm{kg}$ BB dan fraksi etil asetat akar 
pasak bumi $100 \mathrm{mg} / \mathrm{kg}$ BB selama 10 minggu dimulai dari minggu ke-6 sampai minggu ke-16 dan diberikan Doxorubicin $1,17 \mathrm{mg} / \mathrm{kg}$ BB selama 5 minggu sebanyak 1x seminggu dimulai dari minggu ke-6 sampai ke-10, setelah itu dilakukan pembedahan.

\section{Pemeriksaan Ekspresi NF-K $\beta$}

Penelitian ini menggunakan mouse monoclonal antibody NF-K $\beta$. Prosedur yang digunakan untuk imunohistokimia dalam penelitian ini prosedur dari Laboratorium Patologi Anatomi, RSUP Dr. Sardjito Yogyakarta. Jaringan blok parafin dipotong dengan ketebalan 3 mikron. Letakkan diatas ob glass Poly L Lysin. Letakkan obyek glass di inkubator suhu 45 derajat $\mathrm{C}$, biarkan semalam. Diparafinasi setelah itu cuci dengan air kran mengalir,cuci dengan aguadest. Preparat dinkubasi dengan $\mathrm{H}_{2} \mathrm{O}_{2}$ $3 \%$ selama 15 menit, lalu dicuci dengan air kran mengalir. Untuk collagen 1: Retrivel dengan buffer citrat $\mathrm{pH}$ didinginkan kurang lebih selama 30 menit lalu dicuci PBS 2x selama 3-5 menit. Inkubasi dengan blocking serum atau normal serum selama 15 menit, tiriskan, bersihkan tepi-tepinya.Inkubasi dengan primer antibodi NF-K $\beta$ dan Caspase-8 (1:100) lalu dicuci PBS 2x selama 3-5 menit. Inkubasi dengan antibody sekunder atau trekkie universal link selama 20 menit lalu dicuci PBS 2x selama 3-5 menit. Inkubasi dengan trekkie avidin HRP selama 10 menit lalu dicuci PBS 2x selama 3-5 menit. Teteskan cromogen DAB ( 1:50), biarkan selama 2 menit lalu dicuci dengan air. Counterstain dengan Hematoxylin mayer 2 menit lalu dicuci dengan air. Celupkan ke Alkohol bertingkat $70 \%, 96 \%, 100 \%$, Xylol, Mounting. Ekspresi NF-K $\beta$ diamati menggunakan mikriskop cahaya, pada jaringan kanker payudara dianalisis secara kualitatif dengan melihat gen yang terekspresi berwarna coklat sedangkan yang tidak terekspresi berwarna ungu atau biru.

\begin{abstract}
Analisis data
Data yang diperoleh dalam percobaan ini yaitu berupa jumlah sel yang terekspresi NF-K $\beta$, yang terekspresi berwarna coklat sedangkan yang tidak terekspresi berwarna ungu atau biru. Kemudian dari data tersebut dilakukan perhitungan \% ekspresi imunohistokimia. Persen ekspresi masing-masing kelompok dianalisis secara statistik menggunakan komputer program SPSS 19 for windows.
\end{abstract}

\section{HASIL DAN PEMBAHASAN}

\section{Identifikasi Tanaman Akar Pasak Bumi}

Identifikasi tanaman perlu dilakukan untuk menghindari kesalahan dalam pengumpulan bahan dan mendapatan kebenaran identitas dari tanaman yang digunakan yaitu akar pasak bumi.Tanaman akar pasak bumi diperoleh dari Martapura (Kalimantan Selatan). Identifikasi dilakukan di Laboratorium Biologi FMIPA Universitas Ahmad Dahlan Yogyakarta. Hasil menunjukkan bahwa tanaman tersebut benar tanaman akar pasak bumi (Eurycoma longifolia Jack).

\section{Pembuatan Fraksi Etil Asetat Ekstrak Etanol Akar Pasak Bumi}

Maserasi dilakukan dengan merendam dan mengaduk 4150 gram serbuk kering akar pasak bumi dengan pelarut etanol $70 \%$ dalam wadah maserasi. Hasil akhir didapat ekstrak etanol akar pasak bumi seberat 121,36 gram dengan ciri organoleptis berwarna coklat gelap, berasa pahit, kental dan tercium bau khas. Rendemen ekstrak etanol akar pasak bumi adalah sebesar 2,92\%. Pertimbangan menggunakan pelarut etanol $70 \%$ karena etanol $70 \%$ bersifat semipolar, sehingga 
senyawa aktif akar pasak bumi yang bersifat semi polar terlarut didalamnya. Fraksinasi dilakukan dengan penambahan pelarut etil asetat yang lebih non polar dibandingkan dengan etanol untuk memperkecil komponen senyawa yang tertarik ke pelarut etil asetat. Ekstrak etanol akar pasak bumi difraksinasi dengan perbandingan 1:2,5 (etil asetat : ekstrak). Pemilihan fraksi etil asetat sebagai pelarut berdasarkan pada penelitian-penelitian sebelumnya yang menyatakan bahwa pada sel T47D fraksi etil asetat ekstrak etanol akar pasak bumi mempunyai aktivitas sitotoksik yang lebih besar daripada fraksi tidak larut etil asetat.

Kromatografi Lapis Tipis (KLT) merupakan metode analisis yang digunakan untuk menganalisis secara kualitatif senyawa kandungan akar pasak bumi pada penelitian ini. Analisis senyawa pada KLT didasarkan pada nilai $\mathrm{R}_{\mathrm{f}}$ (Retention factor) dibandingkan dengan standar. Proses ini bertujuan untuk melihat kebenaran bahwa fraksi yang didapat mengandung senyawa flavonoid, kuasinoid, alkaloid. Fase diam yang digunakan dalam penelitian ini adalah silika gel $\mathrm{F}_{254}$ sedangkan fase geraknya adalah $\mathrm{CHCl}_{3}$ : Metanol (4:1). Hasil KLT menunjukkan sampel berfluoresensi biru pada UV $254 \mathrm{~nm}$ dan berfluoresensi kuning pada UV $366 \mathrm{~nm}$. Ekstrak akar pasak bumi lebih banyak bercak yang ditimbulkan dibandingkan fraksi etil asetat, hal ini dikarena pelarut etanol merupakan pelarut semipolar yang dapat menyari banyak senyawa sehingga dilakukan proses fraksinasi agar senyawa yang tersari lebih spesifik. Didapatkan hasil sampel memiliki nilai $R_{f}$ yaitu $0,55[2]$.

\section{Uji Aktivitas Ko-Kemoterapi Fraksi Etil Asetat Ekstrak Etanol Akar Pasak Bumi}

Tikus betina galur Sprague Dawley digunakan sebagai hewan uji pada penelitian ini, pemilihan Tikus SD ini dikarenakan lebih sensitif dibandingkan galur Wistar yang dapat menimbulkan kanker dalam rentang waktu yang lebih cepat.

Senyawa7,12dimetilbenz(a)antrasen (DMBA) merupakan agen karsinogen spesifik yang digunakan pada penelitian ini untuk memicu terjadinya kanker payudara, Metabolit aktif DMBA yaitu DMBA-3,4diol, metabolit ini nantinya dioksidasi oleh CYP1A1 atau CYP1B1 menjadi metabolit ultimate carcinogenic (DMBA-3,4-diol1,2 epoxide). Enzim CYPIAI dan CYPIBI ini diekspresikan baik dalam hati dan payudara dimana kedua enzim ini dapat diinduksi oleh DMBA. Dosis senyawa 7,12-dimetilbenz(a)ntrasen (DMBA) yang digunakan adalah $20 \mathrm{mg} / \mathrm{kgBB}$ selama 5 minggu pemberian seminggu 2 kali. Penggunaan minyak jagung pada pemberian DMBA yaitu sebagai pelarut DMBA, sehingga DMBA akan lebih mudah diberikan pada hewan uji secara oral. Agen kemoterapi yang digunakan untuk terapi kanker payudara yaitu Doxorubicin, namun mekanisme aksi Doxorubicin tidak selektif terhadap sel kanker, sehingga obat ini juga bersifat toksik pada sel normal.

Akar pasak bumi dapat digunakan sebagai ko-kemoterapi pada kanker payudara yang menggunakan kemoterapi Doxorubicin, hal ini karena akar pasak bumi memiliki senyawa bioaktivitas kuasinoid, alkaloid dan flavonoid. Kandungan utama dari kuasinoid adalah eurikomanon yang memiliki efek antikanker, oleh karena itu akar pasak bumi dapat digunakan sebagai agen ko-kemoterapi untuk menghambat proliferasi sel kanker dan mencegah kerusakan sel normal akibat penggunaan Doxorubicin melalui aktivitas antioksidan 
dari kandungan flavonoid karena memiliki gugus hidroksi fenolik.

\section{Ekspresi NF-K $\beta$}

Keluarga protein NF-K $\beta$ merupakan salah satu keluarga faktor transkripsi yang penting dalam regulasi ekspresi gen yang terkait dengan fungsifungsi biologis seperti halnya respon imun dan inflamasi, pertumbuhan dan proliferasi sel, serta pertahanan sel terhadap stres (sinar UV, iradiasi, oksidan, kerusakan DNA, termasuk radiasi dari suatu senyawa karsinogen). Pengamatan terhadap ekspresi NF-K $\beta$ pada kelenjar mamae dilakukan untuk mengetahui mekanisme penghambatan dari Kokemoterapi Akar pasak Bumi. Sel kanker yang mengekspresikan NF-K $\beta$ akan memberikan warna cokelat atau gelap, sedangkan yang tidak mengekspresikan NF-K $\beta$ akan berwarna ungu.

Hasil pengamatan menunjukkan bahwa pada tikus yang diberikan perlakuan DMBA sel-sel pada jaringan tumornya terlihat berwarna cokelat yang menunjukkan adanya ekspresi NF-K $\beta$ yang relative tinggi. Adapun sel-sel tumor tikus yang diberikan perlakuan Fraksi Etil Asetat akar pasak bumi terlihat bahwa Fraksi Etil Asetat akar pasak bumi dapat mempunyai aktivitas dalam menghambat ekspresi NF-K $\beta$. Overekspresi NF-K $\beta$ ditemukan dalam kasus-kasus kanker terkait dengan adanya inflamasi pada kanker. Pencarian penghambatan ekspresi NF-K $\beta$ ditujukan untuk menurunkan keterjadian kanker dan menurunkan proliferasi kanker. Dengan mekanisme tersebut maka sel kanker menjadi tidak berkembang dengan adanya penghambatan ekspresi NF-K $\beta$.

Berdasarkan Gambar 1 terlihat bahwa Fraksi Etil Asetat akar pasak bumi dapat mempunyai aktivitas dalam menghambat ekspresi NF-K $\beta$. Overekspresi NF-K $\beta$ ditemukan dalam kasus-kasus kanker terkait dengan adanya inflamasi pada kanker. Pencarian penghambatan ekspresi NF-K $\beta$ ditujukan untuk menurunkan keterjadian kanker. Penghambatan ekspresi NF-K $\beta$ menyebabkan tidak terjadinya aktivasi asam arakhidonat menjadi prostaglandin yang merupakan senyawa yang terlibat dalam karsinogenesis melalui pemacuan proliferasi, angiogenesis, serta penghambatan terjadinya apoptosis. Dengan mekanisme tersebut maka sel kanker menjadi tidak berkembang dengan adanya penghambatan ekspresi NF-K $\beta$.

Hasil Nilai rata-rata \% ekspresi NF-K $\beta$ pada masing-masing Kelompok berturut-turut yaitu $(6,64 \pm 11,28) \%$, $(39,53 \pm 16,49) \%, \quad(18,10 \pm 15,08 \%$, $(16,66 \pm 12,51) \%$ dan $(15,39 \pm 8,76) \%$. Pada kelompok perlakuan DMBA hal ini dikarenakan pemberian perlakuan senyawa 7,12-dimetilbenz(a)antrasen, senyawa ini merupakan karsinogen kimiawi yang mampu menginduksi terjadinya kanker (Meiyanto et al., 2007). Sedangkan pada kelompok perlakuan DMBA + Doxorubicin, DMBA + Akar Pasak Bumi, DMBA + Doxorubicin + Akar pasak Bumi pada kelompokkelompok ini mengalami penurunan ekspresi NF-K $\beta$ dibandingkan kelompok perlakuan DMBA hal ini dikarenakan kombinasi dari pemberian doxorubicin dan akar pasak bumi sebagai agen kokemoterapi bisa menurunkan ekspresi protein NF-K $\beta$. Fraksi etil asetat akar pasak bumi dalam mekanisme antikankernya melalui pemacuan perbaikan DNA yang rusak. Akar pasak bumi memiliki kandungan 3 senyawa bioaktif yaitu kuasinoid, alkaloid, dan flavonoid. Kandungan utama dari kuasinoid adalah eurykomanon yang memiliki efek anti kanker (Nurkhasanah et al, 2008). Hasil persentase rata-rata ekspresi Protein NF-K $\beta$ menunjukkan adanya perbedaan yang signifikan antar kedua kelompok perlakuan sehingga Kokemoterapi fraksi etil asetat akar pasak bumi dan Doxorubicin dapat menurunkan Ekspresi Protein NF-K $\beta$. 
Pemberian Ko-Kemoterapi Fraksi Etil Asetat Akar Pasak Bumi (Eurycoma longifolia Jack) terhadap Ekspresi Protein NF-K $\beta$ pada Tikus Sprague Dawley yang Diinduksi DMBA
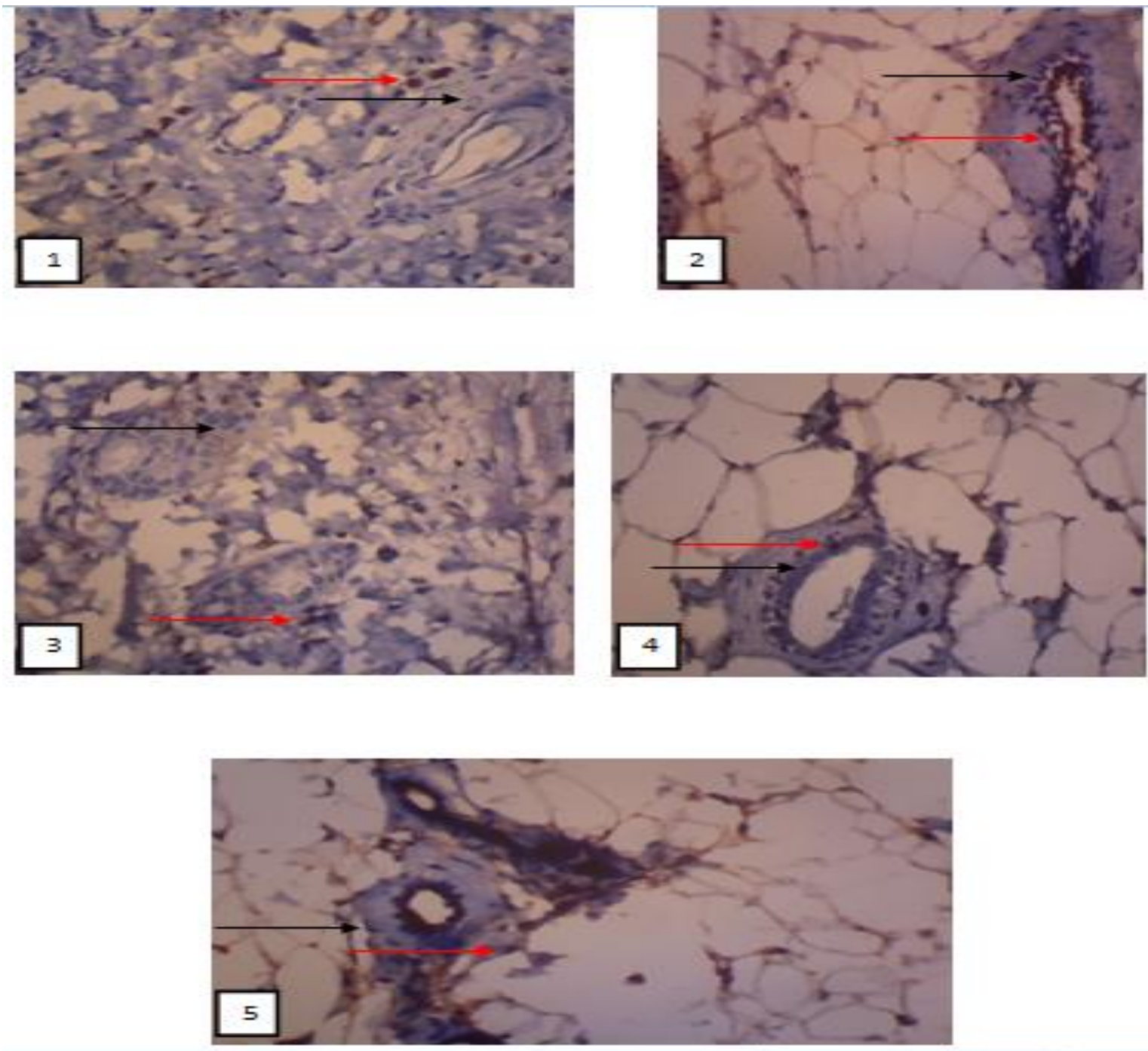

Gambar 1. Foto mikroskopis hasil perbesaran 400x uji imunohistokimia NF-K $\beta$ (1) Kontrol sehat (2) Kelompok DMBA $20 \mathrm{mg} / \mathrm{kg}$ BB (3) Kelompok DMBA $20 \mathrm{mg} / \mathrm{kg}$ BB+Doxorubicin 1,17 mg.kg BB (4) Kelompok DMBA 20 mg/kg BB+APB 100 mg.kg BB (5) DMBA $20 \mathrm{mg} / \mathrm{kg}$ BB+ Doxorubicin 1,17 mg/kg BB+ APB 100 $\mathrm{mg} / \mathrm{kg} \mathrm{BB}$.

Table I Hasil pengamatan rata-rata persentase ekspresi NF-K $\beta$ setelah diberikan perlakuan $\pm \mathrm{SD}$

\begin{tabular}{cc}
\hline Kelompok & Rata-Rata Persen Ekspresi NF-K $\boldsymbol{\beta}(\%) \pm$ SD \\
\hline SEHAT & $6,64 \pm 11,28$ \\
DMBA & $39,53 \pm 16,49$ \\
DMBA+Doxo & $18,10 \pm 15.08$ \\
DMBA+APB & $16,66 \pm 12.51$ \\
DMBA+Doxo+APB & $15,39 \pm 8,76$ \\
\hline
\end{tabular}


Pemberian Ko-Kemoterapi Fraksi Etil Asetat Akar Pasak Bumi (Eurycoma longifolia Jack) terhadap Ekspresi Protein NF-K $\beta$ pada Tikus Sprague Dawley yang Diinduksi DMBA

\section{KESIMPULAN}

Hasil penelitian yang telah dilakukan, dapat disimpulkan bahwa Pemberian kombinasi fraksi etil asetat ekstrak etanol akar pasak bumi (Eurycoma longifolia Jack) dengan dosis 100 $\mathrm{mg} / \mathrm{KgBB}$ dan Doxorubicin 1,12 $\mathrm{mg} / \mathrm{KgBB}$ dapat menurunkan ekspresi protein NF-K $\beta$ pada tikus galur Sprague dawley yang di induksi DMBA.

\section{DAFTAR PUSTAKA}

1. Araki K, K Kawauchi and N Tanaka, 2008, IKK/NF-K $\beta$ signaling pathway inhibits cell-cycle progression by a novel $\mathrm{Rb}$-independent suppression system for E2F transcription factors. Macmillan Publishers Limited. Department of Molecular Oncology, Institute of Gerontology, Nippon Medical School, Kanagawa, Japan.

2. Arifah, A. N., dan Nurkhasanah, 2014, Efek Fraksi Etil Asetat Ekstrak Etanol Akar Pasak Bumi (Eurycoma longifolia, Jack)terhadap Aktivitas Fagositosisi Makrofag secara In Vitro, Pharmaçiana, Vol (4) No.1: 9-1.

3. Hollander, M. C., Kovalsky, O., Salvador, J. M., Kim, K. E., Patterson, A. D., Haines, D. C., et al, 2001, DimetilBenz(a)antrasena

Carcinogenesis in Gadd45a-null Mice Is Associated with Decreased DNA Repair and Increased Mutation
Frequency, Cancer Research 61, 2487-2491.

4. Istighfari, R., \& Meiyanto, E. 2009. Aplikasi Ko-Kemoterapi Fraksi Etil Asetat Ekstrak Etanolik Daun Sambung NYawa (Gynura Procumbens (Lour). Merr) Pada sel Kanker Payudara Mcf-7 , Majalah Ilmu kefarmasian, Vol. VI, No, 132141.

5. Jemal A . 2008. Cancer statistic, CA Cancer J Clin 58:2

6. Meiyanto E, Susilowati S, Tasminatun S, Murwanti R, Sugiyanto, 2007, Efek

kemopreventif ekstrak etanolik Gynura procumbens (Lour.), Merr pada karsinogenesis kanker payudara tikus, Majal Farm Ind 154-161

7. Nurkhasanah M, Azimahtol HLP: Eurycomanone Induces Apoptosis through the Up Regulation of p53 in Human Cervical Carcinoma Cells. Journal of cancer molecules 2008, 4:109-115.

8. Thi Van Anh Tran, Clemens Malainer, Stefan Schwaiger, Atanas G. Atanasov, Elke H. Heiss, Verena M. Dirsch, and Hermann Stuppner. 2014. NF-K $\beta$ Inhibitors from Eurycoma longifolia. Journal of Natural Products. American Chemical Society and American Society of Pharmacognosy.

9. Wang S, Liu Z, Wang L, Zhang X. 2009. NFkappa $\beta$ signaling pathway, inflammation and colorectal cancer. Cell Mol Immunol.;6(5):327-34.) 